\title{
MOLECULAR CHARACTERIZATION OF BREAST CANCER IN YOUNG BRAZILIAN WOMEN
}

Leda Viegas de Carvalho ${ }^{*}$, Emílio Marcelo Pereira², Lucien Frappart ${ }^{3}$, Mathieu Boniol ${ }^{4}$, Wanderley Marques Bernardo ${ }^{5}$, Vicente Taricone ${ }^{6}$, Sean Tavtigian $^{7}$, Melissa Caroline SoutheY ${ }^{8}$

Study conducted at Centro Universitário Lusíada, Santos, SP

*Correspondência:

Av. Siqueira Campos, 634 -

apto 43 Boqueirão

Santos-SP

CEP: $11045-200$

\begin{abstract}
SUMMARY
OвJective. To evaluate the distribution of molecular subtypes of breast tumors diagnosed in young Brazilian women and to analyze the frequency of loss of heterozygocity (LOH) in BRCA1 among different molecular subtypes of early-onset breast cancer.

MEthods. Samples from 72 cases of invasive breast carcinoma diagnosed in women aged between 19 and 40 years were evaluated using an immunohistochemical panel of biomarkers. Three intragenic BRCA1 locus microsatellites, D17S1322, D17S1323, and D17S855, were PCR amplified from matched normal (lymphocyte) and tumor DNAs for ( $\mathrm{LOH}$ ) analysis.

Results. We found 13 cases (18\%) that had an immunohistochemical profile consistent with being basal-like. Forty cases (55\%) were luminal A type; $11 \%$ (8 cases) were luminal B type, 13\% (9 cases) were HER2-overexpressing tumors and two cases were ER-/HER2- carcinomas lacking basal marker expression. Four of the 16 informative cases at D17S1322, one of the four informative cases at D17S855, and none of the five informative cases at D17S1323 displayed LOH (four basal-like and one Luminal A). Microsatellite instability (MSI) at D17S855 and D17S1322 was found in two cases (one a basal-like and one Luminal A).

Conclusion. In our study, basal-like tumor was the second most frequent molecular type among young Brazilian women and was only observed in women diagnosed under the age of 35 years. There was no significant difference of $\mathrm{LOH}$ at BRCA1 locus rates between basal-like breast tumors and not-basal-like breast tumors $(p=0.62)$. $\mathrm{LOH}$ in BRCA1 and MSI in these breast cancers were not frequent but may indicate a small group of breast cancers with a specific molecular makeup.
\end{abstract}

KEY WORDS: Breast neoplasms. Immunohistochemistry. Genes, BRCA1. Loss of heterozygosity. Microsatellite instability.

\section{INTRODUCTION}

Breast cancer represents a heterogeneous group of lesions in terms of clinical presentation, pathological features and outcome, reflecting their molecular complexity and biological diversity. Gene expression profiling analysis has defined five molecular subgroups of breast cancer with different prognoses that include luminal A and luminal B types, basal-like type, ERBB2-overexpressing type and normal breast tissue-like ${ }^{1-5}$. The luminal $A$ and basal-like subtypes have been identified and validated as the two main subtypes of breast cancer which have been associated with the most diverse outcomes. Basal-like tumors have been associated with shorter overall and disease-free survival period and luminal A type tumors have been correlated with good prognosis. Luminal A tumors are characterized by high expression of estrogen receptor (ER) gene and expression of several other genes that are expressed in luminal epithelial cells of the breast ${ }^{4,5}$. Basal-like breast carcinomas, as defined by gene expression profile, present low to absent expression of estrogen receptor gene and expression of genes related to basal epithelial cells of breast tissue, including cytokeratins 5 (CK5) and 17 (CK17) and laminin ${ }^{4,5}$. This subtype of breast cancer accounts for $15 \%$ of

1. Doutora - Professora de Patologia do Curso de Medicina do Centro Universitário Lusíada - UNILUS e Chefe da Seção de Anatomia Patológica-Hospital Guilherme Álvaro, Santos, SP

2. Médico Patologista - Responsável pelo Serviço de Anatomia Patológica do Laboratório Salomão \& Zoppi, São Paulo, SP

3. MD - Patologista, L'Hôpital Edouard Herriot, Lyon, France

4. PhD - Early Detection and Prevention - Prevention Group-International Agency for Research on Cancer- Lyon-France

5. Professor Doutor; Professor de Metodologia de Pesquisa e Medicina Baseada em Evidências - Curso de Medicina do Centro Universitário Lusíada - UNILUS, Santos, SP

6. Mestre - Professor de Ginecologia do Curso de Medicina do Centro Universitário - UNILUS, Santos, SP

7. PhD - Head, Genetic Susceptibility Group- International Agency for Research on Cancer- World Health Organization- Lyon-France

8. PhD - Department of Pathology, The Melbourne University, Victoria-Australia 
all breast carcinomas and affects mainly younger patients and has been associated with carcinomas showing high histological grade, high proliferative rate, frequent TP53 somatic mutations and poor prognosis ${ }^{4,5}$. In clinical practice, breast cancers have been primarily classified using the immunohistochemical results for estrongen receptor (ER), progesterone receptor (PR) and HER2 protein, protein expression ${ }^{6-11}$. Triple-negative breast carcinomas (TNBC) lack ER, PR and HER2 expression. Triple-negative carcinomas account for $10-17 \%$ of all breast carcinomas ${ }^{10,11}$. Both basal-like tumors and TNBC affect mainly young, AfricanBrazilian women and are correlated with poor prognosis. Notwithstanding the overlap between these two entities, it has been described that patients with triple negative breast cancers expressing basal markers had a significantly shorter diseasefree survival than those with triple negative cancers lacking the expression of basal markers ${ }^{10,11}$. Basal-like tumors correspond to the group of ER-negative and HER2-negative tumors that express at least one basal marker, several of which have been assessed in immunohistochemical panels including cytokeratins 5/6, 14 and 17 and P-cadherin ${ }^{8-11}$. HER1 (EGFR) expression has also been associated with basal-like tumors and could be useful to identify basal-like tumors and select patients for new target therapies ${ }^{7,10,11}$. Breast cancers arising in carriers of $B R C A 1$ germline mutations are commonly of the basal epithelial phenotype t2-14 $^{4}$. Luminal A type tumors are ER-positive and HER2negative whereas luminal B are ER-positive and HER2-positive. The HER2-overexpressing tumors group is that of ER-negative and HER2-positive carcinomas and expression of basal markers in this group is variable using immunohistochemistry assay ${ }^{8}$.

Approximately $13 \%$ of breast cancers occur in young women between 20 and 44 years of age. Breast cancer arising in young women is correlated with lower survival and higher incidence of negative clinicopathologic features when compared with older counterparts ${ }^{16}$. The high prevalence of basal-like cancers among premenopausal African-American women could contribute to the poor prognosis of young African-American women with breast cancer $^{10}$

Germline mutations in the two major breast cancer susceptibility genes, BRCA1 and BRCA2, contribute to a proportion (40-70\%, depending upon definition and setting) of breast and ovarian cancers in multiple-case families. They also contribute disproportionately to early-onset breast cancer even in the absence of family history. BRCA1 and BRCA2 are tumor suppressor genes and are classically understood to require a functional loss of both alleles before tumorigenesis proceeds. Thus, in germline mutation carriers, tumor progression depends on loss of the wild-type allele, often molecularly detectable as loss of heterozygosity $(\mathrm{LOH})^{17,18}$. However, $\mathrm{LOH}$ at the BRCA1 and BRCA2 loci has been detected in $20 \%$ and $70 \%$ of sporadic breast and ovarian cancers respectively, leaving open the possibility that these two susceptibility genes could be involved in a proportion of breast cancer in non-mutation carriers ${ }^{17-21}$.

In this study we evaluated the distribution of molecular subtypes of breast tumors in a group of very young Brazilian women using an immunohistochemical panel of biomarkers on tissue microarray (TMA) to address the frequency of basallike carcinomas among this special group of women with breast cancer. Concerning the overlapping between TNBC and basal-like tumors, we also compared the immunohistochemical expression of different basal markers among breast carcinomas according to the ER and HER2 expression to evaluate their association. We also performed a $\mathrm{LOH}$ analysis within BRCA1 to evaluate $\mathrm{LOH}$ in BRCA1 among different molecular subtypes of early-onset sporadic breast cancer.

\section{Methods}

\section{Breast cancer case selection}

Samples from 72 cases of invasive breast carcinoma diagnosed in young women aged between 19 and 40 years (mean age 34) from 2000 to 2005, were analyzed in this study. Paraffin blocks of tumor samples and histologically normal breast tissue from each case were collected from pathology departments of Hospital Guilherme Alvaro- Santos- Sao Paulo State, Brazil and private laboratories in Santos and Sao Paulo (Sao Paulo State, Brazil). All cases were submitted to histological review of haematoxylin-eosin stained slides to confirm diagnosis and evaluate the histological type (WHO Histological Classification of Tumors of the Breast) and histological grade (Elston, Ellis) ${ }^{22}$ of their breast tumors.

None of the patients presented bilateral tumor at diagnosis or had any previous diagnosis of breast and/or ovarian cancers. In two cases, tumors were associated with pregnancy. Ethics approval was obtained from the IRB of the International Agency for Research on Cancer, Lyon, France.

\section{Tissue microarray construction}

Tissue microarray (TMA) blocks were prepared by extracting $0.6 \mathrm{~mm}$ diameter cores of representative areas of tumors from the original paraffin blocks using a Beecher Instruments tissue core extractor and then re-embedding the cores into recipient TMA blocks. Six TMA blocks were constructed containing 12 cases each and each case was presented by 4 to 6 cores that corresponded to different representative areas from each tumor. Cores of liver and normal breast tissue were placed as reference points in the TMA blocks. Thirty serial histological $3 \mu \mathrm{m}$ sections for each block were prepared and a Haematoxylin-Eosin stained section from each block was reviewed to confirm presence of appropriate representative areas of the original lesion.

\section{Immunohistochemistry}

Each set of 6 TMAs was stained with commercially available antibodies: ER (RabMab clone SP1- Neomarkers, USA- readyto-use); HER2 (clone NCL-L-CB11- Novocastra, UK- 1:200); Keratin 5 Ab-1 (clone XM26-Neomarkers, USA- ready-to-use); Keratin 14 Ab-1 (clone LL002- Neomarkers, USA- ready-to-use); P-cadherin (clone 56- BD Transduction Laboratories, USA1:2000); Keratin 8 Ab-4 (clone TS1- Neomarkers, USA- 1:400); EGFR (HER1) (clone EGFR.113- Neomarkers, USA- ready-touse). Antigen retrieval was done for all markers by boiling the tissue sections in $10 \mathrm{mM}$ citrate buffer, $\mathrm{pH} 6.0$ for 20 minutes, followed by cooling at room temperature for 20 minutes. After washing in a phosphate buffer solution (PBS), endogenous peroxidase activity was blocked by incubation in 3\% hydrogen peroxide solution in methanol (Merck, Germany). The slides were incubated with a blocking serum (Vector, USA) for 20 minutes and then incubated with specific primary antibody. A one hour 
room temperature incubation was used for all markers. Detection was obtained by Impress kit (Vector, USA) with diaminobenzidine chromogen as per routine protocol. Tissues were then counterstained with Haematoxylin and coverslipped using a permanent mounting solution. An additional TMA block containing several cores of normal breast tissue, breast tumors, and normal skin was constructed and used as positive control for ER, keratins 5, 14 and 8, and P-cadherin. Positive control slides for EGFR staining were provided by Neomarkers-USA. Negative control (omission of the primary antibody) was performed for each marker.

\section{Interpretation of immunohistochemistry}

A modified histochemical score (H-score) was applied for ER, keratins (CK) 5, 14 and 8 and P-cadherin staining. This score combined an assessment of intensity of staining and percentage of positivity. Intensity was scored as $0,1,2$, or 3 corresponding to negative, weak, moderate or strong positivity. In addition, the percentage of positive was calculated by counting the total number of cells, and number of cells stained for each intensity using an image analysis program, UTHSCSA-Image Tool for Windows version 3.0. The score was calculated $(0 \mathrm{x}$ negative \%) ( 1 x weak \%) ( 2 x moderate \%) ( 3 x strongly stained $\%)$. The score ranged from 0 to 300 . Each core was scored individually and a mean of the informative cores was obtained for each tumor. If only one informative core ( $>50 \%$ of core with tumor) was obtained, the overall score applied was the absolute $\mathrm{H}$-score. Membranous and cytoplasmic immunoreactivity were considered positive for keratins. Mostly membranous and occasional cytoplasmic immunoreactivity were considered positive for P-cadherin staining. Nuclear staining for ER was considered positive and membranous staining for EGFR in more than $10 \%$ of neoplastic cells was considered as positive. One observer (L.C.) scored all cases. HER2 staining was evaluated by two observers (L.C and L.F) using the Herceptest criteria; only cases classified as 3 were considered HER2 positive.

\section{Microdissection and DNA Extraction}

Microdissection of targeted tissue was performed using a Laser microdissection pressure catapult system (P.A.L.M ${ }^{\circledR}$ Microlaser Technologies, Germany) , on PALM ${ }^{\circledR}$ Membrane Slides prepared according to routine protocol and containing $3 \mu \mathrm{m}$ tissue sections stained with Mayer's hematoxylin. Cells from the target tissue were carefully selected and catapulted (approximately 1000 cells) into $10 \mu \mathrm{l}$ of catapult buffer (0.5 M EDTA pH 8.0; $1 \mathrm{M}$ Tris pH 8.0; Igepal CA-630 (Sigma, USA); deionized water) in the cap of a $0.5 \mathrm{ml}$ eppendorf tube, and were mixed with $40 \mu \mathrm{l}$ of catapult buffer and $5 \mu \mathrm{l}$ of Proteinase $\mathrm{K}(20 \mathrm{mg} / \mathrm{ml})$. Eppendorf tubes were incubated for 72 hours at $55^{\circ} \mathrm{C}$. After 72 hours, the Proteinase $\mathrm{K}$ was inactivated by heating at $99^{\circ} \mathrm{C}$ for 15 minutes followed by immediate cooling to $0^{\circ} \mathrm{C}$. The tubes containing the prepared DNA were stored at $-20^{\circ} \mathrm{C}$.

\section{PCR amplification/LOH analysis}

Three intragenic BRCA1 locus microsatellites, D17S1322, D17S1323, and D17S855, were PCR amplified from matched normal (lymphocyte) and tumor DNAs. Oligonucleotide primers for these markers were retrieved from the Genome Database (http://www.gdb.org). The forward primers were fluorescently end-labeled with 5'HEX (D17S855); 5'FAM (D17S1322) and 5'FAM (D17S1323) (MWG Biotech, Ebersberg, Germany). PCR reactions of $25 \mu \mathrm{l}$ volume were performed in $2.5 \mu \mathrm{l}$ of buffer (10mM Tris- $\mathrm{HCl}, \mathrm{pH} 8.0$ ), $0.75 \mu \mathrm{l}$ of $50 \mathrm{mM} \mathrm{MgCl}, 1.5 \mu \mathrm{l}$ of each Primer $(10 \mathrm{mM}), 1.0 \mu \mathrm{l}$ of dNTP $(5 \mu \mathrm{M}), 0.125 \mu \mathrm{l}$ of Taq DNA polymerase (5unit/ $\mu$ l-Platinum ${ }^{\circledR} \mathrm{Taq}$ DNA Polymerase- Invitrogen, USA), $4 \mu \mathrm{l}$ of prepared DNA and $15.2 \mu \mathrm{l}$ of $\mathrm{H}_{2} \mathrm{O}$. Following initial denaturation (at $95^{\circ} \mathrm{C}$ for $5 \mathrm{~min}$ ), 45 cycles of PCR $\left(95^{\circ} \mathrm{C}\right.$ for $30 \mathrm{~s}$; $58^{\circ} \mathrm{C}$ for 30 s and at $72^{\circ} \mathrm{C}$ for $30 \mathrm{~s}$ ) and a final extension (at $72^{\circ} \mathrm{C}$ for $5 \mathrm{~min}$ ) were performed. PCR products $(2.0 \mu \mathrm{l})$ were mixed with formamide and a Rox-labeled molecular weight standard and analyzed in a model ABI PRISM automated DNA sequencer (Applied Biosystems, Foster City, USA) according to the manufacturers protocol. Differences in the relative allele intensity ratio measured by the area under the curve using ABIPRISM Genotyper $^{\circledR}$ Software version 3.7.NT (Applied Bisystems, Foster City, USA) between tumor and normal DNA were indicative of $\mathrm{LOH}$ for a given marker.

\section{Statistical analysis}

We used the Fisher exact and Chi square tests (SAS software, version 8.2, SAS Institute, Cary, NC) to assess differences in the proportion of basal marker expression in different breast cancer phenotype groups and the LOH frequency among the molecular subtypes of breast tumors. Results with $p<0.05$ on a two-sided test were regarded as significant.

\section{RESULTS}

\section{Histopathology findings}

Table 1 shows a summary of the histological types and grades of the 72 assessed breast cancers from very young Brazilian women. Sixty three cases (88\%) were invasive ductal carcinoma, not otherwise specified (NOS), four were invasive lobular carcinoma type, two were of medullary carcinoma type, two were of atypical medullary carcinoma type and one was a mixed carcinoma (ductal and lobular carcinoma). Three cases were grade I, 40 cases (55.5\%) were grade II, and 29 cases $(40.2 \%)$ were grade III. Data related to stage pT and pN were available in 56 cases and 38 cases respectively. Forty-five cases presented tumors larger than $2.0 \mathrm{~cm}(2.5 \mathrm{~cm}-11.0 \mathrm{~cm})$ and twenty-five cases had metastasis in axillary nodes $(\mathrm{N})$.

\section{Immunohistochemistry}

Biomarkers were evaluated for all 72 cases. As all ER-/HER2tumors are potentially basal-like, we evaluated the expression of basal markers among the different subgroups of breast tumors according to their ER/HER2 protein expression profile in order to evaluate which candidate basal marker would be most useful in an immunohistochemical panel to identify the basal phenotype. We found that 13 of 15 cases (86.6\%) of ER negative/ HER negative tumors had a basal-like immunohistochemical profile. Of these, 60\% expressed keratin 5/6 (CK5/6) (figure 1) and $73.3 \%$ were positive for P-cadherin (Figure 2) Table 2. EGFR (HER1) expression was limited to ER negative/HER2 negative tumors, however only 5 of 15 cases were positive for EGFR expression. Our results show that CK 5/6 expression was more frequent among ER negative and HER2 negative tumors than among ER positive and HER2 positive tumors $0.12(0.04$ 


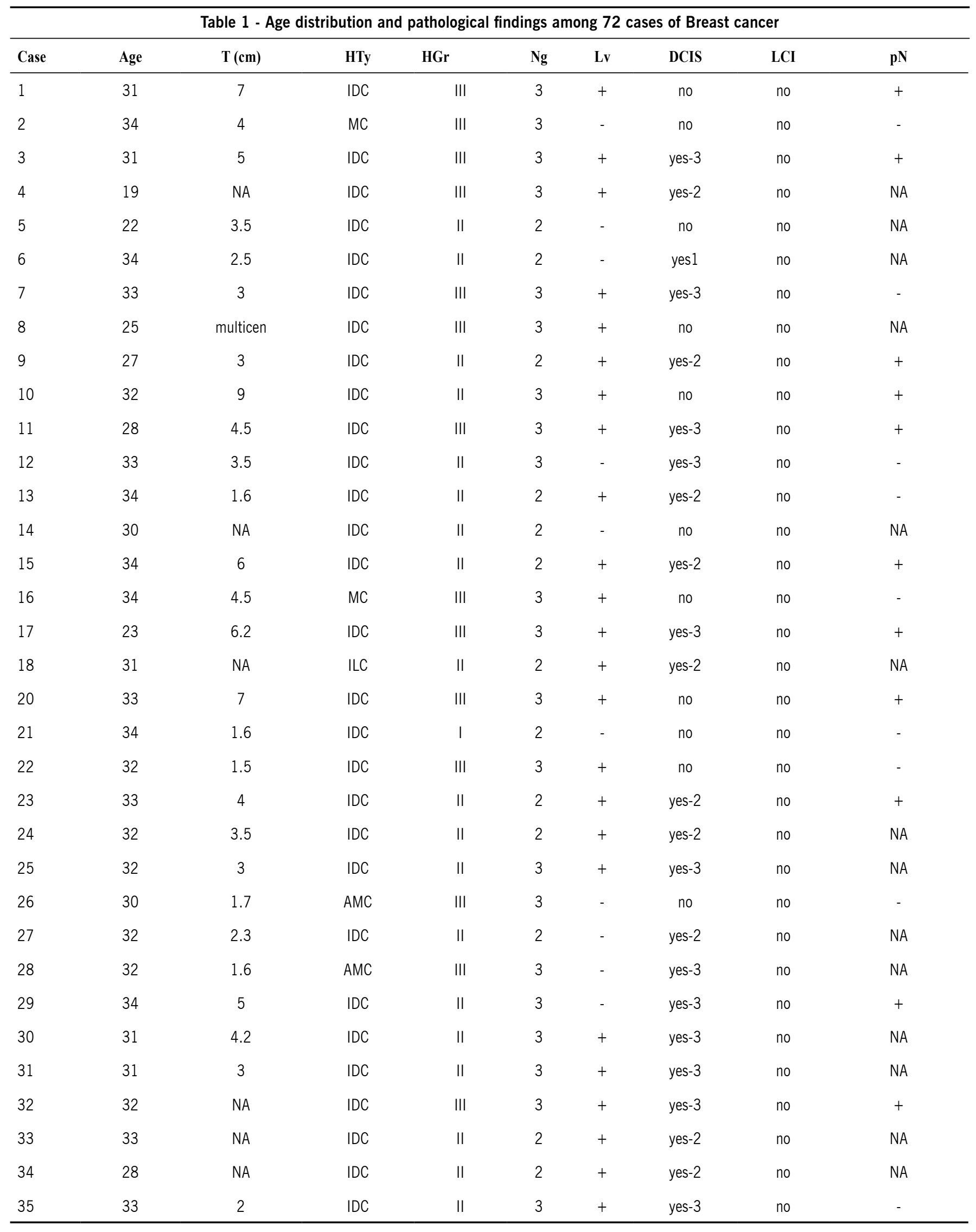




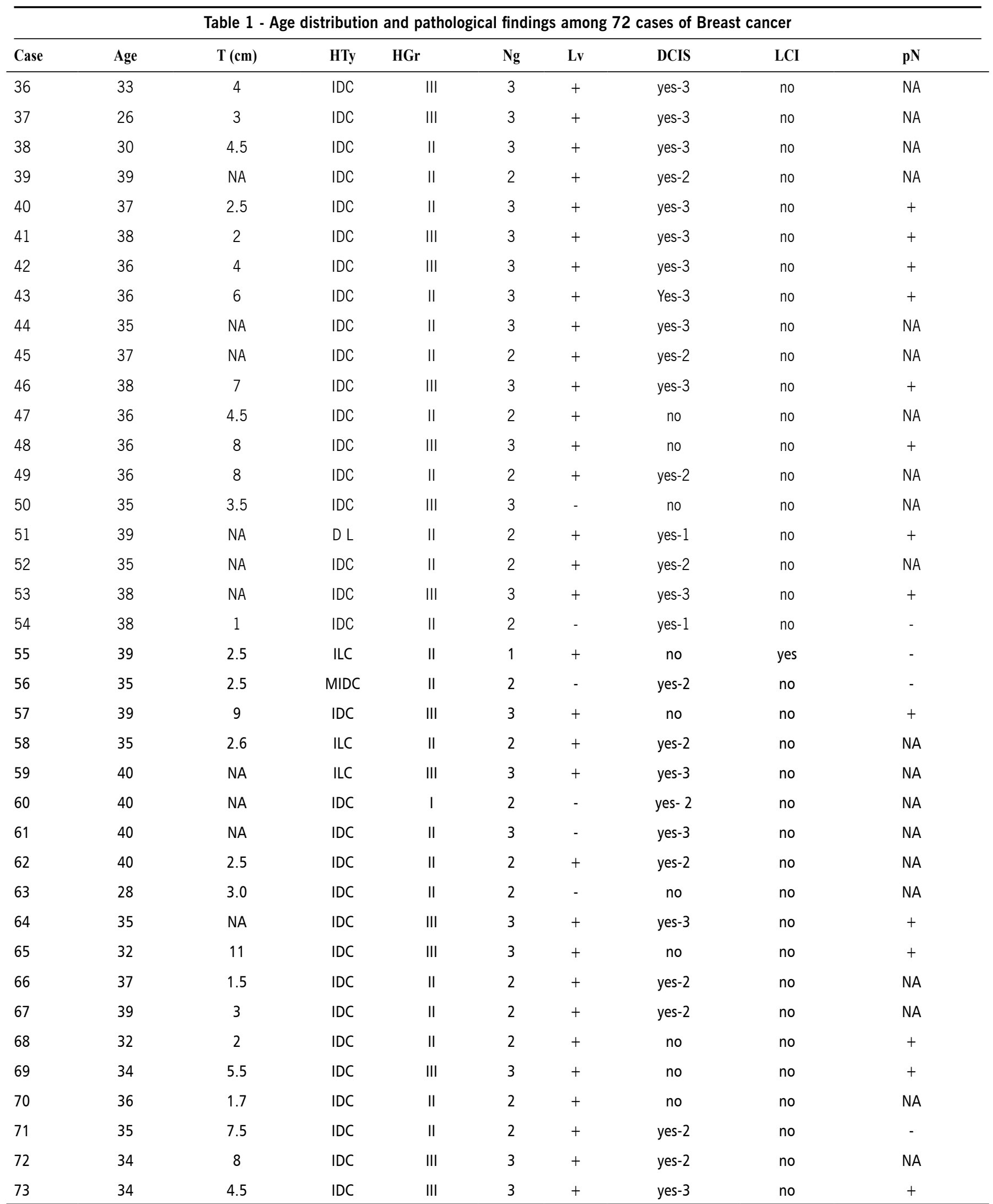

$\mathrm{Ag}=$ Age; $\mathrm{HTy}=$ histologic type; $\mathrm{HGr}=$ histologic grade (Elston-Ellis); $\mathrm{NGr}=$ nuclear grade; $\mathrm{T}=$ Tumour size (cm); LV=Lymphatic invasion; $\mathrm{N}=$ nodal status; $\mathrm{DCIS}=\mathrm{Ductal}$ carcinoma in situ (yes or no and Van Nuys group); LCIS= Lobular carcinoma in situ (yes or no); NA= Not available; MIDC= Microinvasive Ductal carcinoma 


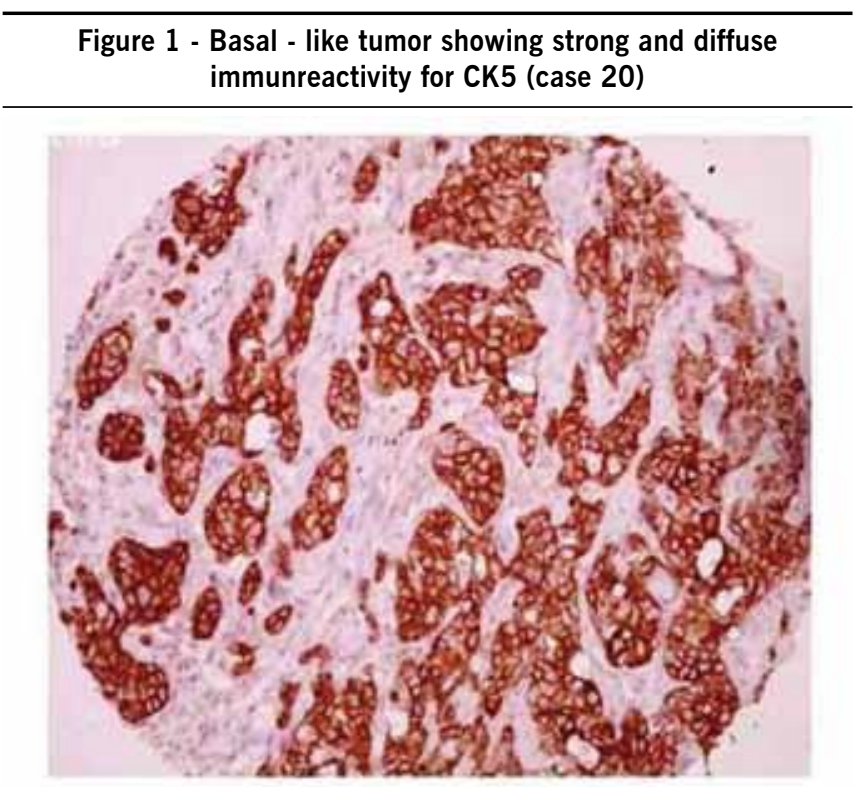
P-cadherin (case 20)

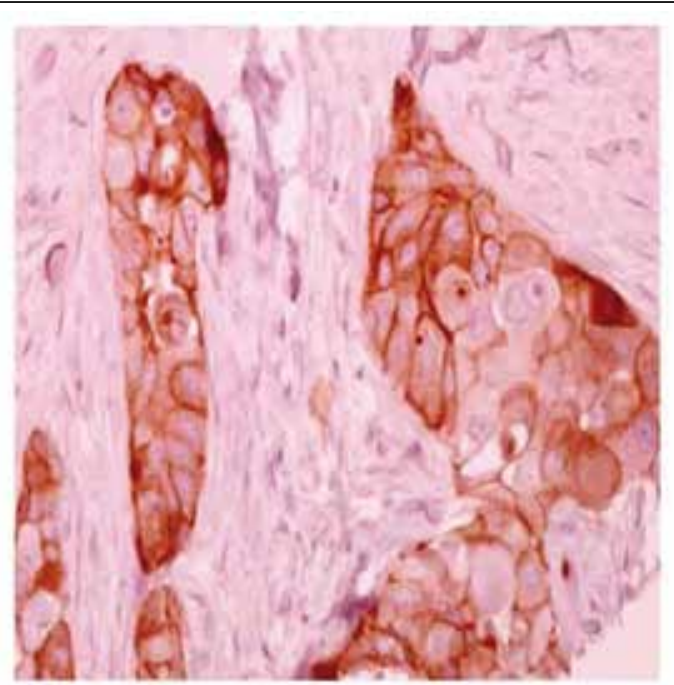

\begin{tabular}{|c|c|c|c|c|c|}
\hline Basal Marker & $\begin{array}{l}\text { ER-/HER2- } \\
n=15(\%)\end{array}$ & $\begin{array}{c}\text { ER-/HER2 } \\
n=9(\%)\end{array}$ & $\begin{array}{l}\text { ER /HER2- } \\
n=40(\%)\end{array}$ & $\begin{array}{c}\text { ER /HER2 } \\
n=8(\%)\end{array}$ & $\begin{array}{c}\text { Total } \\
72\end{array}$ \\
\hline CK5 + & $9(60)$ & 1 (11.1) & $1(25)$ & 0 & \\
\hline CK5 - & $6(40)$ & $8(88.9)$ & $39(97.5)$ & $8(100)$ & $p<.0001$ \\
\hline Pcadherin + & $11(73.3)$ & $6(66.6)$ & $4(10)$ & $2(25)$ & \\
\hline Pcadherin - & $4(26.7)$ & $3(33.3)$ & $36(90)$ & $6(75)$ & $p<.0001$ \\
\hline HER $1+$ & $5(33.3)$ & 0 & 0 & 0 & \\
\hline HER1 - & $10(66.6)$ & $9(100)$ & 40 (100) & $8(100)$ & \\
\hline CK14 + & $5(33.3)$ & $2(22.2)$ & $2(5)$ & 0 & \\
\hline CK14 - & $10(66.6)$ & $7(77.78)$ & $38(95)$ & $8(100)$ & \\
\hline
\end{tabular}

Figure 3 - LOH in BRCA1 (D17S1322) in basal-like tumor (case 20)

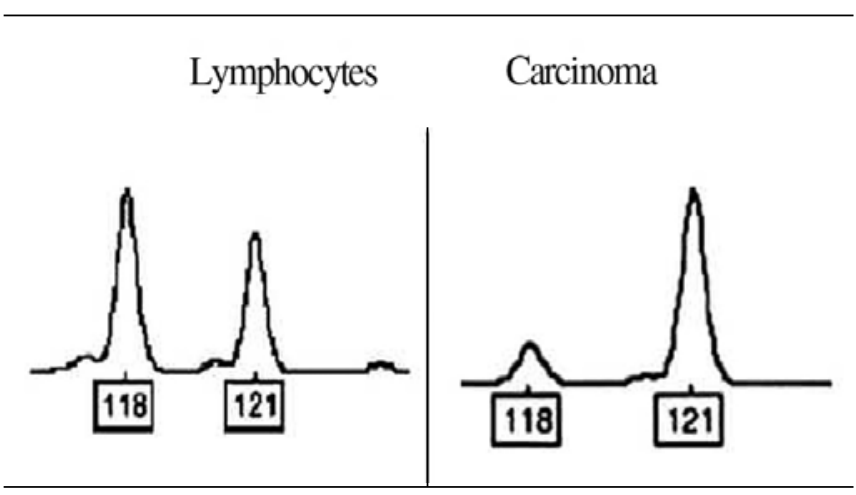

to $0.19-\mathrm{Cl} 95 \%)$ and $0.5(0.24$ a $0.46-\mathrm{Cl} 95 \%)$ respectively (Tables 3 and 4). P-cadherin expression was frequent among ER negative carcinomas 0.30 (0.0 a 0.41- C195\%) (Tables 3 and 4 ). Our results showed that CK14 did not provide additional information compared to CK5 and P-cadherin expression (Tables 3 and 4). High $\mathrm{H}$-score values for $\mathrm{CK} 5 / 6$ and P-cadherin were found among ER negative/HER2 negative tumors. Only two cases of ER-/HER2- tumors were negative for all epithelial basal markers included in our panel. These tumors need additional investigation in order to clarify their molecular portrait. Basallike tumors were restricted to patients younger than 35 years-old (19-34 years-old).

According to these criteria, 55\% (40 cases) of the examined tumors were luminal A (ER /HER2-); 18\% (13 cases) were basallike, $11 \%$ (8 cases) were luminal B (ER /HER2), and 13\% (9 


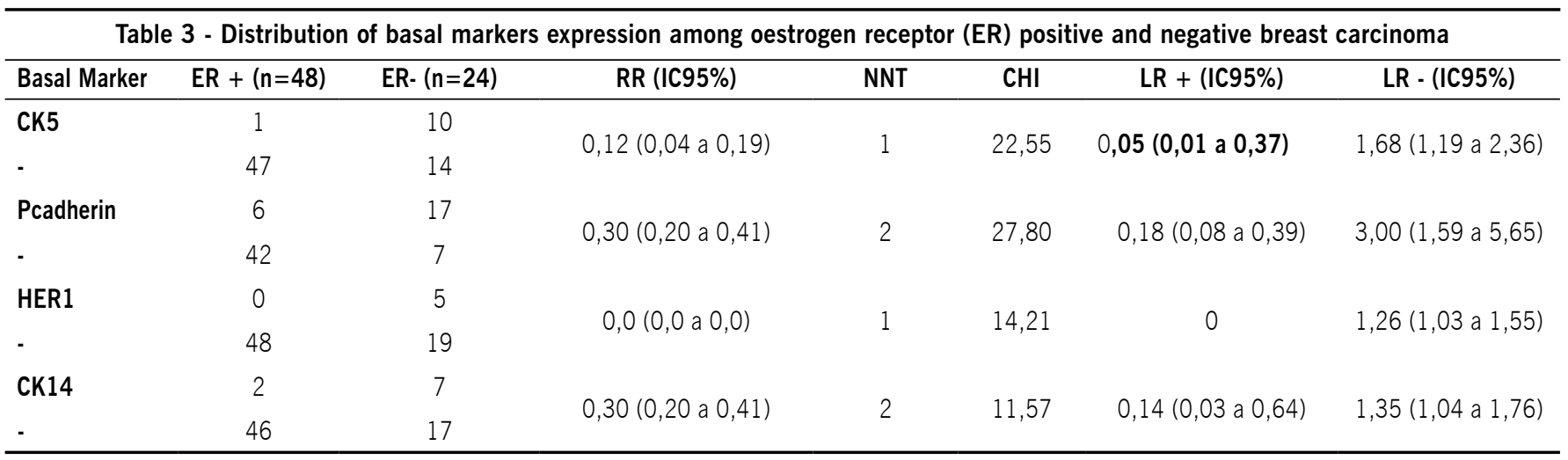

Table 4 - Distribution of the basal markers expression among HER2 positive and HER2 negative breast carcinomas

\begin{tabular}{|c|c|c|c|c|c|c|c|}
\hline \multirow{3}{*}{$\begin{array}{l}\text { Basal Marker } \\
\text { CK5 }\end{array}$} & HER2 $+(n=17)$ & HER2- $(n=55)$ & RR (IC95\%) & NNT & $\mathrm{CHI}$ & LR + (IC95\%) & LR - (IC95\%) \\
\hline & 1 & 10 & \multirow{2}{*}{$0,35(0,24$ a 0,46$)$} & \multirow{2}{*}{6} & \multirow{2}{*}{2,62} & \multirow{2}{*}{$0,32(0,04$ a 2,35$)$} & \multirow{2}{*}{$1,15(0,97$ a 1,37$)$} \\
\hline & 16 & 45 & & & & & \\
\hline Pcadherin & 8 & 15 & \multirow{2}{*}{$1,89(1,59$ a 2,19$)$} & \multirow{2}{*}{-6} & \multirow{2}{*}{1,52} & \multirow{2}{*}{$1,73(0,89$ a 3,35$)$} & \multirow{2}{*}{$0,73(0,45$ a 1,17$)$} \\
\hline- & 9 & 40 & & & & & \\
\hline HER1 & 0 & 5 & \multirow{2}{*}{$0,0(0,0$ a 0,0$)$} & \multirow{2}{*}{4} & \multirow{2}{*}{3,37} & \multirow{2}{*}{0} & \multirow{2}{*}{$1,1(1,01$ a 1,20$)$} \\
\hline & 17 & 50 & & & & & \\
\hline CK14 & 2 & 7 & $0,93(0,88$ a 0,99$)$ & 63 & 0,28 & $0,92(0,21$ a 4,04$)$ & $1,01(0,83$ a 1,24$)$ \\
\hline
\end{tabular}

\begin{tabular}{|c|c|c|c|c|}
\hline $\begin{array}{l}\text { Subtypes of breast } \\
\text { tumour }\end{array}$ & $\begin{array}{c}\text { Informative Cases } \\
\text { D17S1322 } \\
\text { (No. of LOH) }\end{array}$ & $\begin{array}{c}\text { Informative Cases } \\
\text { D17S855 } \\
\text { (No. of LOH) }\end{array}$ & $\begin{array}{c}\text { Informative Cases } \\
\text { D17S1323 } \\
\text { (No. of LOH) }\end{array}$ & $\begin{array}{c}\text { Informative Cases } \\
\text { (any one marker) } \\
\text { (No. of LOH) }\end{array}$ \\
\hline Basal-like & $7(3)$ & $4(1)$ & $4(0)$ & $15(4)$ \\
\hline Not Basal-like & $9(1)$ & 0 & $1(0)$ & $10(1)$ \\
\hline Total & $16(4)$ & $4(1)$ & $5(0)$ & $25(5) p=0.62$ \\
\hline
\end{tabular}

cases) were HER2-overexpressing tumors (ER- / HER2 ). All medullary carcinomas (4 cases), classic and atypical, were positive for P-cadherin and fell into the basal-like tumor group. While 11 cases of basal-like tumors were invasive ductal carcinoma NOS, grade III, we did not find any significant correlation between molecular subgroups and histopathological varibles (type, grade, $\mathrm{pT}$ or pN).

\section{LOH-analysis in BRCA1}

A total of 168 DNA samples from matched normal (lymphocytes) and corresponding tumor tissues were prepared for analysis. We obtained acceptable marker performance for 33 tumor-normal pairs at D17S1322, 19 pairs at D17S855, and 15 pairs at D17S1323. We found 16 informative cases for D17S1322 (48.5\%); four informative cases for D17S855 (21\%) and five informative cases for D17S1323 (33.3\%). Our results showed LOH in four of 16 informative cases (25\%) at D17S1322 and one of four informative cases at D17S855. Of the five cases with $\mathrm{LOH}$ at the BRCA1 locus, immunohistochemical analysis revealed that four were basal-like tumors (cases 4, 17, 20 and 22) and the fifth was a luminal B tumor (case 66). In addition, we noted microsatellite instability (MSI) in BRCA1 at D17S855 and D17S1322 in two cases, one a basal-like tumor and the other a luminal A tumor. Frequencies of $\mathrm{LOH}$ are summarized in Table 4. Data related to family history of breast and/or ovarian cancer were available in only $10 \%$ of cases and no cases were identified as having a family history of breast cancer.

\section{Discussion}

Basal-like breast cancers are an important group of breast cancers, especially among young women in whom they are more commonly observed. This group of breast cancers displays more aggressive clinical behavior and has poorer prognosis ${ }^{1-5}$, is more commonly observed in carriers of germline BRCA1 mutations 
and often contains somatically acquired TP53 mutations. The basal-like group also express molecules, candidates to be targets for specific therapies such as HER $1^{6-11}$. For these reasons it is fundamentally important that these cancers be identified, at the time of diagnosis, for adequate clinical management (appropriate surgery, therapy and referral to clinical genetics if required ) can be provided ${ }^{6-11,23}$

Although first described via expression array technology, immunohistochemical approaches offer the opportunity to characterize the expression of key molecules that define basallike (and other) breast cancers subgroups even in clinical facilities with minimal resources for molecular profiling. The defining molecular make up of basal-like breast cancers includes lack of ER and ERBB2 expression and thus it is important to utilize additional markers whose expression corresponds to the basallike group. Antibodies to cytokeratin 5/6 (CK5/6), 17 (CK17), 14 (CK14) and other proteins such as EGFR (HER1), P-cadherin, and p63 have been reported as basal markers. Hence, an immunohistochemical panel including antibodies to ER protein, HER2 oncoprotein and additional basal markers could be useful to classify breast carcinomas at molecular level6-11 without highly sophisticated resources. Our results show that CK5/6 and P-cadherin are useful markers to predict basal-like cancers among ER-negative/HER2-negative breast carcinomas in young Brazilian women. This could offer an effective strategy to identify these cancers at the time of diagnosis so that appropriate clinical management could be offered. Immunohistochemistry results are variable, depending on the antibodies and protocols used. Some series have shown that rabbit monoclonal antibodies (RabMab) for hormone receptors and HER2 have presented better results when compared to mouse monoclonal antibodies (Mabs). However, Mabs for ER (6F11) have shown similar results compared to RabMab and Mabs for HER2 and seemed to be more specific than RabMab for HER2 ${ }^{24}$

In our study, we evaluated the immunohistochemical staining using an $\mathrm{H}$-score based on intensity and the percentage of stained cells. Semi-quantitative studies for basal markers have established a cutoff of $10 \%$ or greater for basal cytokeratin staining to designate the tumor as positive for basal markers ${ }^{8}$, 9,11 . In our study using a quantitative approach for staining of the basal markers, we found higher $\mathrm{H}$ scores for $\mathrm{CK} 5$ and $\mathrm{P}$-cadherin among ER negative and HER2 negative tumors, corresponding to much more than $10 \%$ of stained cells. Only two cases of ER-negative and HER2-negative carcinomas, were negative for all basal markers tested in our study and they were classified as triple negative carcinomas (progesterone was negative also). Concerning HER2 overexpression, we found $24 \%$ of breast carcinoma cases with HER2 overexpression, which is in agreement with series for any age group ${ }^{1-8}$. We considered as positive for HER2 only carcinomas classified as 3 staining (according to Herceptest criteria) which correspond to cases that could benefit from a target adjuvant therapy with trastuzumab ${ }^{1-11,23}$

In our study, basal-like tumors were the second most frequent molecular type among young Brazilian women and were only observed in women diagnosed under the age of 35 years. Another study on breast cancer diagnosed in young European women showed similar results ${ }^{25}$. Basal-like carcinomas of the breast have been described as high frequency among premenopausal
African-American women who presented poor survival ${ }^{10}$. The high frequency of basal-like tumors among young women could be an explanation for the biological aggressiveness that has been associated with breast cancer diagnosed in young women when compared to breast cancer diagnosed in older women $8,16,20,25-27$. This issue needs further studies.

Early-onset breast cancer and cancer arising in families with multiple cases of breast and/or ovarian cancer have been associated with $B R C A 1$ and BRCA2 germline mutations. Loss of heterozigosity $(\mathrm{LOH})$ in the BRCA1 and BRCA2 loci has been detected in up to $70 \%$ of sporadic breast and ovarian cancers (not associated with multiple-case families), suggesting that these two susceptibility genes could be involved in carcinogenesis of a larger proportion of breast cancers than just those associated with germline mutations in these genes ${ }^{17,19}$ We found $\mathrm{LOH}$ in four cases of 16 informative cases for the microsatellite marker D17S1322; three of them corresponded to basal like carcinomas. $\mathrm{LOH}$ was detected in one of four informative cases for D17S855. This case corresponded to the triple negative carcinoma. Among Brazilian women with sporadic breast cancer, $\mathrm{LOH}$ in BRCA1 has been previously reported in 10 of 23 informative cases for D17S85521. The present study found the D17S1322 marker to be more frequently informative (than D17S1323 and D17S855) and to identify $\mathrm{LOH}$ in $25 \%$ informative cases. $\mathrm{LOH}$ was detected in five of 25 informative tumors for any one marker, four basallike tumor and one not-basal-like tumor if our measurement of the rates of $\mathrm{LOH}$ at BRCA1 locus in basal-like breast tumors versus not-basal-like tumors is accurate. To obtain a significant difference (e.g.,p_ FET< 0.05) between the two groups, we would have had to screen approximately 100 informative tumors.

Although germline BRCA1 status information of these cases is not available, our data suggest that $\mathrm{LOH}$ in $B R C A 1$ of breast cancers arising in young Brazilian women is not frequent and may be only as frequent as the anticipated germline $B R C A 1$ mutation positive cases (estimated to be in the order of 10 of the 72 cases in this study, extrapolating from other populationbased data relevant to early-onset breast cancer) ${ }^{27,28}$. Certainly the breast cancer subtype of the cases in which we observed $\mathrm{LOH}$ at BRCA1 (4/5 were basal-like) is consistent with the subtype commonly observed in BRCA 1 mutation carriers ${ }^{10-15}$. However, the number of informative cases for any marker in our study was low, maybe reflecting technical limitations due to the kind of tissue used (formalin fixed and paraffin embedded tissue) for DNA extraction from the microdissected lymphocytes.

While there appears to be no increased risk of breast cancer in hereditary nonpolyposis colorectal cancer (HNPCC) ${ }^{29,30}$, we and many others have reported that a proportion of breast cancers arising in carriers of MMR gene mutations in the context of HNPCC exhibit molecular pathological evidence that the MMR gene dysfunction is associated with tumorigenesis of the breast ${ }^{31,32}$. MSI has been detected in a wide variety of human neoplasms associated with and without a family history of cancer and represents diagnostic criteria for mismatch repair deficiency ${ }^{33,34}$. Reports of MSI in breast cancer outside the context of HNPCC are variable. Studies have identified a low frequency of MSI in sporadic breast cancer compared to $\mathrm{LOH}^{35,36}$. A study of $\mathrm{MSI}$ in BRCA1 and breast cancer arising in Chinese women showed a global rate of $\mathrm{MSI}$ of $46 \%{ }^{37}$. MSI at locus D17S855 
and has also been identified in $19 \%$ of gastric cancer in a Chinese population ${ }^{38}$. We identified MSI at D17S1322 locus in two cases, one basal-like carcinoma (medullary carcinoma) and another, a luminal A tumor (invasive ductal carcinoma grade II). Significance of these observations and possible association of these two cases with MMR deficiency are currently unknown. MSI in breast cancers outside the context HNPCC could potentially be an identifier of a group of cancers arising from a common but as yet undescribed pathway and warrants further investigation.

Further prospective studies must be conducted to determine the distribution of molecular subtypes of breast cancer arising in women of any age group to evaluate their clinical and prognostic impact in Brazil. These studies will be pursued to analyze the possible correlation between germline mutations in breast cancer susceptibility genes and molecular subtypes of breast tumors and develop strategies to identify young women at the highest risk.

\section{Acknowledgments}

The work reported in this paper was undertaken during the tenure of a Postdoctoral Fellowship from the International Agency for Research on Cancer (IARC). We thank Nicole Lyandrat and Fabrice Odefrey for laboratory assistance. We are most grateful to Dr. Angelo Sementilli (Beneficiência Portugesa Hospital, Santos) and Dr. Galindo Decker (Casa de Saude Hospital, Santos) for contributing to this study by providing case material.

Financial Support: Postdoctoral Fellowship from the International Agency for Reasearch on Cancer- WHO- Lyon- France

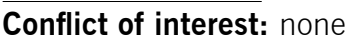

\section{Resumo}

\section{Caracterização molecular do câncer de mama em mulheres BRASILEIRAS JOVENS}

OBJEtIvo. Avaliar a distribuição dos subtipos moleculares dos tumores de mama diagnosticados em mulheres brasileiras jovens e determinar a frequência de perda de heterozigose ( $\mathrm{LOH})$ no gene BRCA1 entre os diferentes subtipos moleculares de tumores.

Métodos. Setenta e dois casos de carcinoma invasivo de mama diagnosticados em mulheres entre 19 e 40 anos de idade foram classificados de acordo com o subtipo molecular utilizando um painel imunoistoquímico e para a análise de LOH foram utilizados três marcadores intragênicos para o gene BRCA1 (D17S1322, D17S855, D17S1323).

RESULTADOS. Treze casos (18\%) apresentaram perfil imunoistoquímico compativel com carcinoma do tipo basal (basal-like tumor). Quarenta casos (55\%) foram classificados como tumores do tipo luminal $A ; 11 \%$ (oito casos) do tipo luminal $B, 13 \%$ (nove casos) corresponderam a tumores com superexpressão de HER2 (HER2-overexpressing tumors) e dois casos corresponderam a carcinomas ER/HER2 negativos sem expressão de marcadores basais. $\mathrm{LOH}$ foi detectada em quatro dos 16 casos informativos para o marcador D17S1322 e em um dos quatro casos informativos para D17S855. Instabilidade de microssatélites (MSI) foi observada em dois casos, um do tipo basalóide e um do tipo luminal $A$.
Conclusão. Carcinomas do tipo "basal-like" corresponderam ao segundo subtipo molecular mais frequente entre os tumores de mama diagnosticados neste grupo de mulheres e foram restritos às mulheres com idade inferior a 35 anos. Não houve diferença significativa na frequência de $\mathrm{LOH}$ no gene $B R C A 1$ entre os subtipos moleculares $(p=0,62)$. A frequência de $L O H$ e de instabilidade de microssatélite em BRCA1 foi baixa neste grupo de pacientes, porém podem indicar um pequeno grupo de cânceres de mama com características moleculares específicas distintas. [Rev Assoc Med Bras 2010; 56(3):278-87]

UnITERmos: Neoplasias da mama. Genes BRCA1. Perda de heterozigosidade. Imunoistoquímica. Instabilidade de microssatélites.

\section{REFERENCES}

1. Perou CM, Sorlie T, Eisen MB, van de Rijn M, Jeffrey SS, Rees CA, Pollack JR, Ross DT, Johnsen H, Akslen LA, Fluge O, Pergamenschikov A, et al. (2000). Molecular portraits of human breast tumours. Nature 406:747-752

2. Sørlie T, Perou CM, Tibshirani R, Aas T, Geisler S, Johnsen H, Hastie T, Eisen M, van de Rijn M, Jeffrey SS, Thorsen T, Quist H, et al. (2001).Gene expression patterns of breast carcinomas distinguish tumor subclasses with clinical implications. Proc Natl Acad Sci USA 98:10869-10874.

3. vant Veer LJ, Dai H, van de Vijver MJ, He DY, Hart AMA, Mao M, Peterse HL, van der Kooy K, Marton MJ, Witteveen AT, Schreiber GJ, Kerkhoven RM, et al. (2002). Gene expression profiling predicts clinical outcome of breast cancer. Nature 415: 530-536

4. Sørlie T, Tibshirani R, Parker J, Hastie T, Marron JS, Nobel A, Deng S, Johnsen H, Pesich R, Geisler S, Demeter J, Perou CM, et al. (2003). Repeated observation of breast tumor subtypes in independent gene expression data sets. Proc Natl Acad Sci USA 100:8418-8423

5. Sotiriou C, Neo SY, McShane LM, Korn EL, Long PM, Jzaeri A, Martiat P, Fox SB, Harris AL, Liu ET. (2003). Breast cancer classification and prognosis based on gene expression profiles from a populationbased study. Proc Natl Acad Sci USA 100:10393-10398

6. van de Rijn M. Perou CM, Tibshirani R, Haas P, Kallioniemi O, Kononen J, Torhorst J, Sauter G, Zuber M, Kochli OR, Mross F, Dieterich H, et al.. (2002). Expression of cytokeratins 17 and 5 identifies a group of breast carcinomas with poor clinical outcome. Am J Pathol 161:1991-1996

7. Nielsen TO, Hsu FD, Jensen K, Cheang M, Karaca G, Hu Z, HernandezBoussard T, Livasy C, Cowan D, Dressler L, Akslen LA, Ragaz J, Gown AM, Gilks CB,, van de Rijn M, Perou CM. (2004). Immunohistochemical and clinical charecterization of the basal-like subtype of invasive breast carcinoma. Clinical Cancer Res 10: 5367-5374

8. Matos I, Dufloth R, Alvarenga M, Zeferino LC, Schmitt F. (2005). p63, cytokeratin5, and P-cadherin: three molecular markers to distinguish basal phenotype in breast carcinomas. Virchow Arch DOI 10.1007/s00428-005-0010-7

9. El-Rehim DM, Ball G, Pinder SE, Rakha E, Paish C, Robertson JFR, Macmillian D, Mlamey RW, Ellis 10 (2005). High-throughput protein expression analysis using microarray technology of a large well-characterized series identifies biologically distinct classes of breast cancer confirming recent cDNA expression analysis. Int J Cancer 116: 340-350

10. Rakha E A, Reis-Filho J, Ellis IO (2008). Basal-like Breast Cancer: a critical review. J Clin Oncol 26: 2568-2581

11. Diaz LK, Cryns VL, Symmans WF, Sneige N. (2007). Triple negative breast carcinoma and basal phenotype: from expression profiling to clinical practice. Adv Anat Pathol 14: 419-430

12. Gusterson B A, Ross DT, Heath VJ, Stein T (2005). Basal cytokeratins and their relationship to the cellular origin and functional classification of breast cancer. Breast Cancer Research 7 (4): 143-148.

13. Foulkes WD, Stefansson IM, Chappuis PO, Bégin LR, Goffin JR, Wong N, Trudel M, Akslen LA. (2003). Germline BRCA1 mutations and basal epithelial phenotype in breast cancer. J Natl Cancer Inst 95:1482-1485

14. Lakhani SR, Reis-Filho JS, Fulford L, Penault-Llorca F, van der Vijver M, Parry S, Bishop T, Benitez J, Rivas C, Bignon Y, Claude JC, Hamann U, et al. (2005). Prediction of BRCA1 stauts in patients with breast cancer using estrogen receptor and basal phenotype. Clin Cancer Res 11: 5175-5180

15. Arnes JB, Brunet J, Stefansson IM, Bégin LR, Wong N, Chappuis O, Akslen LA, Foulkes WD. (2005). Placental cadherin and the basal epithelial phenotype of BRCA1-related breast cancer. Clin Cancer Res 11(11): 4003-4011

16. Dubsky PC, Gnant M F, Taucher S, Roka S, Kandioler D, Pichler-Gebhard B, Agnster I, et al. (2002). Young age is an idependent adverse prognostic factor in premenopausal patients with breast cancer. Clinical Breast Cancer 3: 65-72 
17. Janatova M, Zikan M, Dundr P, Matous B, Pohlriech P. (2005). Novel somatic mutation in the BRCA1 gene in sporadic breast tumours. Human Mutation DOI: 10.1002/humu.9308

18. Knudson AG, Jr (1971). Mutation and Cancer: statistical study of retinobalstoma. Proc. Natl Acad Sci USA 68: 820-823

19. Kollias J, Man S, Marafie M, Carpenter K, Pinder S, Ellis IO, Blamey RW, Cross G, Brook JD (2000). Loss of heterozygosity in bilateral breast cancer. Breast Cancer Res and Treat 64: 241-251

20. Querzoli P, Albonico G, di lasio MG, Ferretti S, Rinaldi R, Cariello A, Pedriali M, Matteuzzi M, Maestri I, Nenci I. (2001). Biophenotypes and survival of BRCA1 and TP53 deleted breast câncer in Young women. Breast Cancer Res and Treat 66: 135-142

21. Santos SC, Cavalli LR, Cavalli IJ, Lima RS, Haddad BR, Ribeiro EMSF. (2004). Loss of heterozygosity of BRCA1 and FHIT genes in patients with sporadic breast cancer from Southern Brazil. J Clin Pathol 57: 374-77

22. Ellis IO, Elston CW (1998). Tumors of the breast. In:Fletcher C, (ed) Diagnostic histopathology of tumors, $2^{\text {nd }}$ edn. Churchill Livingstone, New York

23. Martins SJ, Yamamoto CA (2008). Clinical and economic issues in adjuvant chemotherapy for HER-2 positive breast cancer. Rev Assoc Med Bras. 54(6):494-9

24. Rocha RM, Nunes CB, Sanches FS, Rocha GF, Oliveira FN, Reis-Filho JS, Lambrs MB, Gobbi H (2009). Rabbit antibodies for hormone receptors and HER2 evaluation in breast cancer._Rev Assoc Med Bras.55(2):163-8

25. Planelles $M$, Aranda FI, Niveiro M, Peiro G, Alenda C, Segui J, Palacios J (2006)- Immunohistochemical Phenotype of Invasive Breast Cancer in Young Women. Correlation with Cox-2 and PTEN expression. In: Abstracts of the 95 Th Annual Meeting of USCAP Atlanta, Georgia, 11-17 February

26. Armes JE, Trute L, White D, Southey MC, Hammet F, Tesoriero A, Hutchins AM, Dite GS, McCredie MR, Giles GG, Hopper JL, Venter DJ. (1999). Distinct molecular pathogenesis of early-onset breast cancer in BRCA1 and BRCA2 mutation carriers: A population-based Study. Cancer Research 59: 2011-2017

27. Eerola H, Heikkila P, Tamminen A, Aittomaki K, Blomqvist C, Nevanlinna H. (2005). Relationship of patients' age to histopathological features of breast tumours in BRCA1 and BRCA2 and mutation negative breast cancer families. Breast Cancer Research DOI 10.1186/bcr1025

28. Hopper JL, Southey MC, Dite GS, Jolley DJ, Giles GG, McCredie MR, Easton DF, Venter DJ (1999). Population-based estimate of the average age-specific cumulative risk of breast cancer for a defined set of protein-truncating mutations in BRCA1 and BRCA2. Australian Breast Cancer Family Study. Cancer Epidemiol Biomarkers Prev; 8:741-7.

29. Southey MC, Tesoriero AA, Andersen CR, Jennings KM, Brown SM, Dite GS, Jenkins MA, Osborne RH, Maskiell JA, Porter L, Giles GG, McCredie MR, Hopper JL, Venter DJ. (1999) BRCA1 mutations and other sequence variants in a population-based sample of Australian women with breast cancer. Br J Cancer; 79:34-9.

30. Watson P, Lynch HT (1993) Extracolonic cancer in hereditary nonpolyposis colorectal cancer. Cancer 71:677-85

31. Aarnio M, Mcklin JP, Aaltonen LA, Nystrom-Lahti M, Jarvinen HJ.(1995) Lifetime risk of different cancers in hereditary non-polyposis colorectal cancer (HNPCC) syndrome. Int J Cancer 64:430-433

32. Southey MC, Young MA, Whitty J Mifsud S, Keilar M, Mead L, Trute L, Aittomäki K, McLachlan SA, Debinski H, Venter DJ, Armes JE. (2001) Molecular Pathologic analysis enhances the diagnosis and management of Muir-Torre syndrome and gives insight into its underlying molecular pathogenesis. Am J Surg Path 25:936-941

33. Risinger JI, Barrett JC, Watson P, Lynch HT, Boyd J. (1996) Molecular genetic evidence of the occurrence of breast cancer as an integral tumour in patients with the hereditary non-polyposis colorectal carcinoma syndrome. Cancer $77: 1836-1843$

34. Southey MC, Jenkins MA, Mead L, Whitty J, Trivett M, Tesoriero AA, Smith LD, Jennings K, Grubb G, Royce SG, Walsh MD, Barker MA, Young JP, Jass JR, St John DJ, Macrae FA, Giles GG, Hopper JL. (2005) Mismatch repair gene mutation testing, immunohistochemistry and microsatellite instability testing in a population-based series of unselected early-onset colorectal cancers. J Clin Oncol 23:6524-6532

35. Poweierska-Czarny J, Miscicka-Sliwka D, Czarny J, Grzybowski T, Wozniak M, Drewa G, Czechowicz W, Sir J (2003). Analysis of microsatellite instability and loss of heterozygosity in breast cancer with the use of a well characterized multiplex system. Acta Biochimica Polonica 50: 1195-1203

36. Adem C, Soderberg CL, Cunningham JM, Reynolds C, Sebo TJ, Thibodeau SN, Hartmann LC, Jenkins RB. (2003). Microsatellite instability in hereditary and sporadic breast cancers. Int J Cancer 107:580-582

37. Cui J, Shen F, Jiang F, Wang Y, Bian J, Shen Z.(1998). Loss of heterozygosity and microsatellite instability in the region including BRCA1 of breast cancer in Chinese. Zhonghua Yi Xue Yi Chuan Xue Za Zhi 15: 348-30

38. Chen XR, Zhang WZ, Lin XQ, Wang JW.(2006).Genetic instability of BRCA 1 gene at locus D17S855 is related to clinicopathological behaviors of gastric cancer from Chinese population. World J Gastroenterol 12: 4246-9

Artigo recebido: 13/06/09 Aceito para publicação: 31/01/10 